\section{Fall-planted Cover Crops Support Good Yields of Muskmelons}

\author{
Wilfred Singogo ${ }^{1}$, William J. Lamont, Jr. ${ }^{2}$, and Charles W. Marr ${ }^{3}$ \\ Department of Horticulture, Forestry and Recreation Resources, Kansas State \\ University, Manhattan, KS 66506
}

Additional index words. Cucumis melo, Medicago sativa, Vicia villosa, Pisum sativum subsp. arvense, Triticum aestivum, polyethylene mulch, drip irrigation

\begin{abstract}
Four cover crops \{alfalfa (Medicago sativa L. 'Kansas Common'), hairy vetch (Vicia villosa Roth), Austrian winter pea [Pisum sativum subsp. arvense (L.) Poir], and winter wheat (Triticum aestivum L. 'Tam 107')\}, alone and in combination with feedlot beef manure at $5 \mathrm{t} \cdot \mathrm{ha}^{-1}$ were evaluated for 2 years to determine whether sufficient $\mathrm{N}$ could be supplied solely by winter cover cropping and manure application to produce high-quality muskmelons (Cucumis melo L. 'Magnum 45') in an intensive production system using plastic mulch and drip irrigation. Among the legumes, hairy vetch produced the most biomass $\left(8.9\right.$ t.ha $\left.^{-1}\right)$ and accumulated the most $N\left(247 \mathrm{~kg}^{-h a^{-1}}\right)$. Winter wheat produced more biomass $\left(9.8 \mathrm{t} \cdot \mathrm{ha}^{-1}\right)$ than any of the legumes but accumulated the least $\mathrm{N}\left(87 \mathrm{~kg}^{\mathrm{ha}} \mathrm{h}^{-1}\right)$. Melon yields produced using legume cover crops alone were similar to those receiving synthetic $\mathbf{N}$ fertilizer at 70 or $100 \mathrm{~kg} \cdot \mathrm{ha}^{-1}$. Melons produced on plots with cover crops combined with beef manure did not differ significantly in yield from those produced on plots with only cover crops. Legume cover crops alone, used with plastic mulch and drip irrigation, provided sufficient $\mathbf{N}$ for the production of high-quality muskmelons.
\end{abstract}

Before the advent of widespread synthetic fertilizer use, vegetable producers routinely used livestock manures, soil-improving legumes in rotation with vegetable and agronomic crops, and green manures in their farming operations to supply the nutrients required for their crops (Kelly, 1990). The development of specialized farming operations has resulted in dependence on synthetic fertilizer for vegetable and agronomic crop production and on the use of large commercial feedlots that produce abundant manure in the livestock industry. If not used or stored properly, manure can pollute groundwater with nitrates and contaminate nearby streams.

The liberal application of inorganic $\mathrm{N}$ and $P$ fertilizers in intensive vegetable farming operations may result in pollution of groundwater, lakes, and streams by nitrates and phosphates (Porter, 1975; Power, 1987). There has been increasing concern about the environmental impact of agricultural production practices on surface and groundwater quality, soil erosion, and loss of soil productivity. Additionally, there is an increasing awareness that synthetic $\mathrm{N}$ fertilizers are derived from energy-intensive processes and should be used

Received for publication 8 Sept. 1995. Accepted for publication 27 Sept. 1995. Contribution no. 93-50J from the Kansas Agricultural Expt. Station, Manhattan. Mention of a trademark or proprietary product does not constitute a guarantee or warranty of the product by the Kansas Agricultural Expt. Station and does not imply its approval to the exclusion of other products that may be suitable. The cost of publishing this paper was defrayed in part by the payment of page charges. Under postal regulations, this paper therefore must be hereby marked advertisement solely to indicate this fact.

${ }^{1}$ Graduate Student.

${ }^{2}$ Associate Professor.

${ }^{3}$ Professor. judiciously (Radke et al., 1988; Stivers and lems have contributed to the renewed interest in crop production systems that use organic sources of nutrients.

Soil-improving crops, such as cover crops or green manures, have the capability to trap residual $\mathrm{N}$ remaining in the soil from previous crops. Legumes have the additional capability to fix atmospheric N. A review by Hoyt and Hargrove (1986) concluded that legume cover crops in the southern United States have the potential to accumulate $>150 \mathrm{~kg} \mathrm{~N} / \mathrm{ha}$ that can be available for a subsequent crop. Similar figures have been drawn from other studies on $\mathrm{N}$ contribution by legumes (Blevins et al., 1990; Bruulsema and Christie, 1987; Meelu et al., 1992; Smith et al., 1987). Animal manures can provide a significant source of plant nutrients and supply organic matter to the soil (Eggert and Kahmann, 1984; Simpson, 1986).

Much of the current research on using legumes in rotation and their value as sources of $\mathrm{N}$ is conducted with agronomic crops. Our objective was to determine whether high yields of muskmelons could be produced from $\mathrm{N}$ supplied by overwintering legumes or winter wheat alone and in combination with livestock manure, while incorporating the advantages of drip irrigation and plastic mulches (Loy and Wells, 1975; Shmueli and Goldberg, 1971).

\section{Materials and Methods}

In Fall 1989, a 2-year field study was initiated at the Kansas State Univ. (KSU) Horticulture Farm located near Manhattan. The soil at the site was a Haynie very fine sandy loam (coarse to silty, mixed calcareous, mesic Typic Udifluvent). The initial soil test indicated a $\mathrm{pH}$ of 8.0 and (in $\mathrm{kg} \cdot \mathrm{ha}^{-1}$ ) 36 available N, $71 \mathrm{P}, 415$ exchangeable $\mathrm{K}$, and Shennan, 1991). These concerns and prob-
$1.0 \%$ organic matter (Dahnke, 1988) (Soil Testing Laboratory, KSU, Manhattan). The field had been cropped the previous summer with soybeans (Glycine max L.).

The design was a split-plot with three replications. The main plot was cover crop (alfalfa, hairy vetch, Austrian winter pea, and winter wheat). The split plot was the feedlot beef manure application. The manure was obtained from beef cattle at the KSU Beef Teaching and Research Center that were on a high-protein feed ration [corn (Zea mays L.), sorghum (Sorghum bicolor L.), and silage]. The manure contained no bedding. In 1990, the nutrient composition (on wet basis 55.5\% moisture) for available $\mathrm{N}, \mathrm{P}$, and $\mathrm{K}$ was 9.4 ,

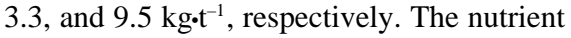
content for 1991 differed slightly, with a moisture content of $61.8 \%$ and available $\mathrm{N}, \mathrm{P}$, and

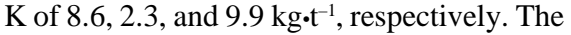
application rate for both years was $5 \mathrm{t}^{\mathrm{h}} \mathrm{ha}^{-1}$, an amount considered adequate to supplement the $\mathrm{N}$ derived from the cover crops for muskmelon production (Lingle and Wight, 1965). Control plots received no treatment or complete fertilizer $(2.9 \mathrm{~N}-5.7 \mathrm{P}-10.8 \mathrm{~K})$ with $\mathrm{N}$ at 70,100 , or $135 \mathrm{~kg} \cdot \mathrm{ha}^{-1}$. The test crop was 'Magnum 45' muskmelon, a netted, western, shipping-type melon.

Cover crops were seeded on 22 Sept. 1989 and 21 Sept. 1990. The seeding rates were 33, 33,72 , and $44 \mathrm{~kg} \cdot \mathrm{ha}^{-1}$ for alfalfa, hairy vetch, Austrian winter pea, and winter wheat, respectively. Austrian winter pea and hairy vetch seeds were inoculated with Rhizobium leguminosarum Frank and alfalfa seeds were inoculated with Rhizobium meliloti Dangeard at the time of seeding. No supplemental irrigation was necessary in 1990, but in Apr. 1991, cover crops were sprinkler-irrigated with 102 $\mathrm{mm}$ water. Manure was applied in early May of each year, just before mowing and plowingin the cover crops. After 3 weeks, the soil was disked and bedded, then, in one operation, plastic mulch $(0.031 \mathrm{~mm}$ thick, $1.2 \mathrm{~m}$ wide, black embossed) and drip irrigation tubing [0.20 $\mathrm{mm}$ thick, emission spacing $30 \mathrm{~cm}$, flow rate of 1.5 liters/min per $30 \mathrm{~m}$ of row at $55 \mathrm{kPa}$ (Roberts Irrigation Products, San Marcos, Calif.)] were applied using recommended commercial practices. Synthetic fertilizer treatments were applied to the plots before bedding. Each main plot consisted of three plasticcovered, 22-m-long rows on $1.5-\mathrm{m}$ centers. 'Magnum 45' muskmelons transplants were grown in 24- $\mathrm{cm}^{3}$ cells for 4 weeks in a greenhouse and transplanted $45 \mathrm{~cm}$ apart on 31 May 1990 and 4 June 1991. Pest control was accomplished using recommended commercial practices with an aim to minimize applications.

Soil water status was measured with tensiometers at 15- and 30-cm depths, and water was applied when water potential at $15 \mathrm{~cm}$ reached $-0.24 \mathrm{kPa}$. Melons were harvested 16 times in 1990, beginning on 27 July and ending 31 Aug., and 19 times in 1991, beginning 31 July and ending 9 Sept. Weight and number of marketable fruit were recorded.

Aboveground biomass of cover crops was sampled on 2 May 1990 and 8 May 1991 using 
a $0.25-\mathrm{m}^{2}$ quadrat (Sarrantonio, 1991). Biomass production and $\mathrm{N}$ content of cover crops were determined on a dry-matter basis (Table 1). Plant samples were dried at $65 \mathrm{C}$, weighed, chopped, and ground to pass through a $2-\mathrm{mm}$ screen. Total $\mathrm{N}$ was determined by the Kjeldahl digestion method.

Three weeks after cover crop plowdown, mineral $\mathrm{N}\left(\mathrm{NO}_{3}-\mathrm{N}\right.$ and $\left.\mathrm{NH}_{4}-\mathrm{N}\right)$ in the soil was determined in the $0-$ to $30-\mathrm{cm}$ depth for all treatments using standard laboratory procedures (Bremner and Mulvaney, 1982; Technicon Industrial Systems, 1977).

Whole aboveground plant samples of muskmelons were collected three times (July, August, and September) during the growing season for biomass and total $\mathrm{N}$ content.

\section{Results and Discussion}

Muskmelon yield. Feedlot manure significantly increased the total number of fruit harvested over that grown without manure only with hairy vetch in 1990 (Table 2) and Austrian winter pea in 1991 (Table 3). Feedlot manure increased the total yield of fruit only with hairy vetch in 1990 . The yield response to increasing rates of synthetic fertilizer indicates that nutrients were limiting in the amended soil. Thus, yield responses to cover crops and manure were likely due to the increased $\mathrm{N}$ associated with these treatments (Table 1). In addition, the similarities in yields between the organic and synthetic fertilizer treatments suggest that cover crops and manure treatments can replace synthetic fertilizers in this cropping system. Although the number of melons per hectare was generally lower in 1991, the trends were similar to those in 1990 (Tables 2 and 3). The lower yields in 1991 were probably due to a period of hot weather, which could have affected melon flowering and fruit set (McGlasson and Pratt, 1962).

Differences in melon yields attributable to production system used were few in both years. In most cases, yields obtained with cover crops alone were not significantly less than yields when manure was included and were commercially satisfactory. The concentration of total soluble solids in melon flesh did not differ with treatment for either year (data not shown).

Muskmelon $N$ accumulation. During July of both years, the greatest accumulation of $\mathrm{N}$ by muskmelon vines and fruit occurred in cover crops receiving manure supplements, but increases due to manure were significant only in 1990 for alfalfa and wheat (Table 2). The same trend in $\mathrm{N}$ accumulation also occurred in August and September (data not shown). The smallest accumulations were with winter wheat alone (1990) and alfalfa alone (1991) (Tables 2 and 3). In 1990, N accumulation by muskmelons tended to increase as the rate of synthetic fertilizer was increased. However, this increase was significant only between 0 and $70 \mathrm{~kg} \mathrm{~N} / \mathrm{ha}$. In 1991, fertilizer rates did not affect $\mathrm{N}$ accumulation.

The results from this study demonstrate that in most cases, melon yields from cover crops supplemented with feedlot cattle manure, cover crops alone, or synthetic fertilizers did not differ significantly.

The lack of manure availability in many areas and its transportation and application costs, as described by Kelly (1990), may offset any improvement in yield. The advantage of using fall-planted and overwintered legumes as an annual crop may appeal to many vegetable growers who, because of limited land resources or high land rent, find tying up land in a more traditional 3- to 4-year legume

Table 1. Aboveground cover crop dry matter production and $\mathrm{N}$ content.

\begin{tabular}{|c|c|c|c|}
\hline \multirow[b]{2}{*}{ Treatment } & \multirow{2}{*}{$\begin{array}{c}\text { Dry wt } \\
\left(\mathrm{kg} \cdot \mathrm{ha}^{-1}\right)\end{array}$} & \multicolumn{2}{|c|}{$\mathrm{N}$ content } \\
\hline & & $\overline{\mathrm{kg}^{\prime} \mathrm{ha}^{-1}}$ & $\%$ \\
\hline \multicolumn{4}{|c|}{1990} \\
\hline \multicolumn{4}{|l|}{ Cover crops } \\
\hline Alfalfa & $2800 \mathrm{~b}^{2}$ & $107 \mathrm{~b}$ & 3.8 \\
\hline Hairy vetch & $5600 \mathrm{a}$ & $233 \mathrm{a}$ & 4.2 \\
\hline Austrian winter pea & $3200 \mathrm{~b}$ & $107 \mathrm{~b}$ & 3.3 \\
\hline Wheat & $4900 \mathrm{ab}$ & $81 \mathrm{c}$ & 1.6 \\
\hline \multicolumn{4}{|c|}{1991} \\
\hline Cover crops & & & \\
\hline Alfalfa & $5700 \mathrm{~d}$ & $138 \mathrm{c}$ & 2.4 \\
\hline Alfalfa + manure & $7600 \mathrm{c}$ & $220 \mathrm{~b}$ & 2.9 \\
\hline Hairy vetch & $8900 \mathrm{~b}$ & $247 a b$ & 2.8 \\
\hline Hairy vetch + manure & $9100 \mathrm{~b}$ & $280 \mathrm{a}$ & 3.1 \\
\hline Austrian winter pea & $7600 \mathrm{c}$ & $230 a b$ & 3.0 \\
\hline Austrian winter pea + manure & $8200 \mathrm{bc}$ & $266 \mathrm{a}$ & 3.2 \\
\hline Wheat & $9800 \mathrm{ab}$ & $87 \mathrm{~d}$ & 0.9 \\
\hline Wheat + manure & $11000 \mathrm{a}$ & $119 \mathrm{~cd}$ & 1.1 \\
\hline
\end{tabular}

${ }^{2}$ For each year, mean separation within columns by Tukey's HSD at $P \leq 0.05$.

Table 2. Melon fruit yield and N (July) accumulation following 1 year of cover crop plus manure application or synthetic fertilizer, 1990.

\begin{tabular}{|c|c|c|c|}
\hline Treatment & $\begin{array}{c}\text { Fruit } \\
\text { (no./ha, 1000s) }\end{array}$ & $\begin{array}{c}\text { Fruit yield } \\
\left(\mathrm{t} \cdot \mathrm{ha}^{-1}\right)\end{array}$ & $\begin{array}{c}\mathrm{N} \text { accumulation } \\
\left(\mathrm{kg} \cdot \mathrm{ha}^{-1}\right)\end{array}$ \\
\hline \multicolumn{4}{|l|}{ Cover crops } \\
\hline Alfalfa & $55 \mathrm{ab}^{\mathrm{z}}$ & $85 \mathrm{ab}$ & $95 \mathrm{c}$ \\
\hline Alfalfa + manure & $60 \mathrm{a}$ & $97 \mathrm{a}$ & $174 \mathrm{a}$ \\
\hline Hairy vetch & $50 \mathrm{~b}$ & $72 \mathrm{~b}$ & $111 \mathrm{bc}$ \\
\hline Hairy vetch + manure & $58 \mathrm{a}$ & $92 \mathrm{a}$ & $131 \mathrm{~b}$ \\
\hline Austrian winter pea & $54 \mathrm{ab}$ & $79 \mathrm{ab}$ & $97 \mathrm{c}$ \\
\hline Austrian winter pea + manure & $55 \mathrm{ab}$ & $83 \mathrm{ab}$ & $111 \mathrm{bc}$ \\
\hline Wheat & $52 \mathrm{~b}$ & $77 \mathrm{~b}$ & $70 \mathrm{~d}$ \\
\hline Wheat + manure & $55 \mathrm{ab}$ & $85 \mathrm{ab}$ & $120 \mathrm{~b}$ \\
\hline \multicolumn{4}{|l|}{ Synthetic fertilizer $N\left(\mathrm{~kg} \cdot \mathrm{ha}^{-1}\right)$} \\
\hline 0 & $48 \mathrm{c}$ & $67 \mathrm{c}$ & $77 \mathrm{~d}$ \\
\hline 70 & $52 \mathrm{~b}$ & $79 \mathrm{~b}$ & $120 \mathrm{~b}$ \\
\hline 100 & $59 \mathrm{a}$ & $89 \mathrm{ab}$ & $135 \mathrm{~b}$ \\
\hline 135 & $60 \mathrm{a}$ & $95 \mathrm{a}$ & $147 \mathrm{~b}$ \\
\hline
\end{tabular}

${ }^{2}$ Mean separation within columns by Tukey's HSD at $P \leq 0.05$.

Table 3. Melon fruit yield and N (July) accumulation following 2 years of cover crop plus manure application or synthetic fertilizer, 1991.

\begin{tabular}{|c|c|c|c|}
\hline Treatment & $\begin{array}{c}\text { Fruit } \\
\text { (no./ha, 1000s) }\end{array}$ & $\begin{array}{c}\text { Fruit yield } \\
\left(\mathrm{t} \cdot \mathrm{ha}^{-1}\right)\end{array}$ & 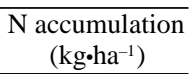 \\
\hline \multicolumn{4}{|l|}{ Cover crops } \\
\hline Alfalfa & $49 b^{2}$ & $82 \mathrm{ab}$ & $102 \mathrm{~b}$ \\
\hline Alfalfa + manure & $50 \mathrm{bc}$ & $100 \mathrm{a}$ & $113 \mathrm{ab}$ \\
\hline Hairy vetch & $51 \mathrm{~b}$ & $77 \mathrm{~b}$ & $123 \mathrm{a}$ \\
\hline Hairy vetch + manure & $52 \mathrm{~b}$ & $82 \mathrm{ab}$ & $126 \mathrm{a}$ \\
\hline Austrian winter pea & $50 \mathrm{bc}$ & $69 \mathrm{bc}$ & $110 \mathrm{ab}$ \\
\hline Austrian winter pea + manure & $53 \mathrm{a}$ & $78 \mathrm{ab}$ & $120 \mathrm{a}$ \\
\hline Wheat & $50 \mathrm{bc}$ & $81 \mathrm{ab}$ & $109 \mathrm{ab}$ \\
\hline Wheat + manure & $52 \mathrm{~b}$ & $81 \mathrm{ab}$ & $121 \mathrm{a}$ \\
\hline \multicolumn{4}{|l|}{ Synthetic fertilizer $N\left(\mathrm{~kg} \cdot \mathrm{ha}^{-1}\right)$} \\
\hline 0 & $44 \mathrm{c}$ & $62 \mathrm{c}$ & $107 \mathrm{ab}$ \\
\hline 70 & $47 \mathrm{bc}$ & $69 \mathrm{bc}$ & $110 \mathrm{ab}$ \\
\hline 100 & $48 \mathrm{bc}$ & $70 \mathrm{bc}$ & $122 \mathrm{a}$ \\
\hline 135 & $50 \mathrm{bc}$ & $76 \mathrm{~b}$ & $124 \mathrm{a}$ \\
\hline
\end{tabular}

${ }^{2}$ Mean separation within columns by Tukey's HSD at $P \leq 0.05$. 


\section{Crop Production}

Bremner, J.M. and C.S. Mulvaney. 1982. Salicylic acid-thiosulfate modification of Kjeldahl method to include nitrate and nitrite, p. 621. In: R.H. Miller and D.R. Keeney (eds.). Methods of soil analysis. Part 2. Amer. Soc. Agron., Madison, Wis.

Bruulsema, T.W. and B.R. Christie. 1987. Nitrogen contribution to succeeding corn from clover. Agron. J. 79:96-100.

Dahnke, W.C. (ed.). 1988. Recommended chemical soil test procedures for North Central region. North Dakota Agr. Expt. Sta. Bul. 499 rev.

Eggert, F.P. and C.L. Kahmann. 1984. Response of three vegetable crops to organic and inorganic nutrient sources, p. 97-109. In: D.F. Bezdicek et al. (eds.). Organic farming: Current technology and its role in sustainable agriculture. Amer. Soc. Agron. Special Publ. 46. Amer. Soc. Agron., Madison, Wis.

Hoyt, G.D. and W.L. Hargrove. 1986. Legume cover crops for improving crop and soil management in the southern United States. HortScience 21:397-402.

Kelly, W.C. 1990. Minimal use of synthetic fertiliz- ers in vegetable production. HortScience 25:168 169.

Lingle, J.C. and J.R. Wight. 1965. Fertilizer experiments with cantaloupes. Calif. Agr. Expt. Sta. Bul. 807. p. 2-22.

Loy, J.B. and O.S. Wells. 1975. Response of hybrid muskmelons to polyethylene row covers and black polyethylene mulch. Scientia Hort. 3:223230.

McGlasson, W.B. and H.K. Pratt. 1963. Fruitset patterns in cantaloupes (Cucumis melo L. var. reticulatis Naud). Proc. Amer. Soc. Hort. Sci. 83:495-505.

Meelu, O.P., R.A. Morris, R.E. Furoc, and M.A. Dizon. 1992. Grain responses in rice to eight tropical green manures. Trop. Agr. (Trinidad) 69:133-136.

Porter, K.S. 1975. Nitrogen and phosphorus-Food production, waste and the environment. Ann Arbor Science, Ann Arbor, Mich.

Power, J.F. 1987. Legumes: Their potential role in agricultural production. Amer. J. Alternative Agr. 2:69-73.

Radke, J.K., R.W. Andrews, R.R. Janke, and S.E.
Peters. 1988. Low-input cropping systems and efficiency of water and nitrogen use, p. 193218. In: W.L. Hargrove and B.G. Ellis (eds.). Cropping strategies for efficient use of water and nitrogen. Special Publ. 51. Amer. Soc. Agron., Crop Sci. Soc. Amer., and Soil Sci. Soc. Amer., Madison, Wis.

Sarrantonio, M. 1991. Methodologies for screening soil improving legumes. Rodale Inst. Res. Ctr., Kutztown, $\mathrm{Pa}$.

Shmueli, M. and D. Goldberg. 1971. Sprinkler, furrow and trickle irrigation of muskmelon in an arid zone. HortScience 6:557-559.

Simpson, K. 1986. Fertilizers and manures. Longman handbooks in agriculture. Wiley, New York.

Smith, S.C., W.W. Frye, and J.J. Varco. 1987. Legume winter cover crops. Adv. Soil Sci. 7:96139.

Stivers, L.J. and C. Shennan. 1991. Meeting the nitrogen needs of processing tomatoes through winter cover cropping. J. Prod. Agr. 4:330-335.

Technicon Industrial Systems. 1977. Industrial method no. 487-77A. Nitrate and nitrite in soil extracts. Tarrytown, New York. 